\title{
Cannes 1995
}

\author{
By Gerald Pratley
}

Fall 1995 Issue of KINEMA

CANNES, THE 48th YEAR -- overcrowded, frequently lost in confusion, outrageously overpriced, an event at which art and idealism, once the hallmarks of the festival, now find it difficult in making their presence felt above the din of the circus entertainment, the crass commercialism and the exploitation of demeaning films. This, the most famous film festival of them all, has become too large for its own good and the ever-increasing costs of mounting it means that whatever makes money becomes the prime consideration of its managers. Once a venue only for people working in film and its related activities, Cannes has now become a public palace for a feverish scramble to see motion pictures most of which may well be playing in regular cinemas within a few months.

True, reputations can still be made in spite of the disadvantages, with some filmmakers becoming favourites of the festival circuit, with others finding wider audiences internationally in cinemas, on video and TV. Acclaim at Cannes however all too frequently and quickly fizzes away once the curtains close over the final performances. One trusts that this will not happen to the brilliant new Canadian film, Le Confessionnal (The Confessional) by Robert Lepage. In writing and directing his first film, this much praised avant-garde artist of theatre, dance and television, noted for his minimalism and obscurantist creations and the flagrant treatment and interpretation of classic works, has come up with a surprisingly lucid if complex mystery story woven around themes relating to the confessional which formed the basis of Hitchcock's I Confess, filmed in Quebec City in 1952. Set in the same places, with touches of the master's symbolism, Lepage tells of a tormented young man's (Lothaire Bluteau) attempts to find his missing brother (Patrick Goyette) and to learn of his family background. Taking place over the years and utilising clever flashbacks, this remarkable film moves along with an assured certainty and an astonishing grasp of film techniques and character portrayal. It is naturally and convincingly Québécois, turning a critical eye on religion and politics without letting these observations hold up the central thrust of the story. The twists and turns, smoothly taken with surprising detours, require rapt concentration and participation by the audience, who will be rewarded by the close.

Every cast member is faultless, although certain reviewers at Cannes found Bluteau lacking in spirit and conviction; poor Bluteau seems to be shot at after every film he has made since taking on Jesus. Kristin Scott Thomas, the highly accomplished English actress (this is a Canada/UK co-production with David Puttnam) goes somewhat awry as Hitchcock's assistant (having been on location for I Confess I can say that she was not like this nor any other director's assistant I have met on an American film), but even this slight flaw does not detract from the whole. It is effectively scored by Sacha Puttnam, splendidly photographed by Alain Dostie catching the Hitchcock style, and deserves to be widely seen. It may not, because I Confess was not one of Hitchcock's better known films coming down to the present generation as does Psycho. Also, being in French with English sub-titles (translated by the always sensitive Robert Gray) may limit its appeal. It is an intelligent, thoughtfully written film, with compelling dialogue, passing from the specialised category into the more widely accepted mainstream where sub-titles are not usually welcomed. But, unless the original actors speak the dialogue in English, dubbing would destroy it. Hitchcock, agreeably played by Ronald Burrage, would certainly have been impressed by this picture.

The Confessional was shown in The Director's Fortnight, a programme for "author-films." Charles Binamé's Eldorado was also shown in this section. Described as being a portrait of Gen X angst this largely improvised hand-held camera "look at life" on the streets of inner city Montréal is for the most part shallow, exploitive and unconvincing. Not until the final third part can one feel sympathy or understanding for its mostly unlikable characters.

Two other Canadian pictures were also invited to official programmes: Clement Virgo's Rude and Stephen Williams' Soul Survivor. The latter was accepted in the Critics' Week and Rude was shown in Un Certain Regard. Heralded as taking its place in the annals of Canadian film as the first dramatic feature to be written, directed and produced by black (Jamaican) filmmakers, this low budget, quickly-made account of "boyz'n the drugs" is to be applauded for its style, acting, mood and photography. Rude is the work of an eager and 
intelligent young director, but one that is seldom illuminating or compelling in its theme and depiction. Of its three episodes, only one succeeds.

Soul Survivor is also set in Toronto's Jamaican community and made by Jamaicans. It portrays ghetto life as seen through the eyes and experience of a young man struggling to make an honest living while resisting the temptations of dubious easy-money activities. This is also a commendable and ambitious first film, stylishly shot and reflecting a lively and imaginative mind at work; but the characters are not fully realised nor clearly defined within the narrative.

Lastly, shown on the Market, a very odd film indeed called Margaret's Museum (formerly The Glace Bay Miners' Museum) directed by Mort Ransen, a drama with its funny side about life in a poverty-stricken Nova Scotia mining village in the late '40s. An uneven script is enlivened by the deeply-felt performances of Helena Bonham Carter, Clive Russell (this too is a Canada/UK co-production) and Kate Nelligan, burnished by Vic Sarin's lovely photography of the Cape Breton region. (It later won the Best Film Prize at the San Sebastian Film Festival.)

Wayne Traudet's short film Movements of the Body (Alberta College of Art) was well received in the Critics' Week programme. Although not a Canadian film as such, Michael Moore's Canadian Bacon (shot in Toronto and Niagara Falls) deserves to be mentioned: a marvelous low-comedy concerning the American invasion of Canada, this is an astute and friendly reading of the Canadian character, made hugely enjoyable by a witty script and the great comedian John Candy. Moore's shots at the American political system and a gullible American public earned him no praise, from either critics or moviegoers, and his courageous picture simply disappeared after its initial release.

This being the 100th Year of the Cinema the French made the most of their part in Cinema History by honouring the Lumière Brothers. Two years ago, the Americans put forward their claim with Edison. It's as though no one anywhere else invented a camera and a projector - prompting Jean-Luc Godard to remark: "It's not the centenary of the cinema that's being celebrated. It's the centenary of the first time anyone paid to get in."

\section{Author Information}

Gerald PRATLEY, OC, LLD, started his career as film critic with the CBC. In 1969, he founded the Ontario Film Institute which he directed until 1990. He has written several books and numerous articles on film, including Torn Sprockets, a history of Canadian cinema. He taught Film History in universities in Toronto and Waterloo, Canada and holds three honorary degrees from Canadian and US universities.

Gerald A. Pratley (1923-2011) was born and educated in London, England, and came to Canada in 1946. He started working in Toronto for the $\mathrm{CBC}$ as a scriptwriter. He was drawn toward working in motion pictures, and became, in 1948, the CBC's first film critic and commentator.

Gerald Pratley broadcast three programmes a week, Pratley at the Movies, The Movie Scene, Music From the Films, and others, until 1975. During this time he also became the first post-war chairman of the Toronto Film Society, chairman of the Toronto and District Film Council and co-founder of the A-G-E Film Society and correspondent for international magazines such as Films and Filming, Film In Review, Variety, Hollywood Quarterly and International Film Guide. During the 1950s he wrote for Canadian Film Weekly and Canadian Film Digest.

He became known as a speaker on all aspects of motion picture art and industry, and was invited to teach film history at the University of Toronto, York University, University of Waterloo, Seneca College and Ryerson Polytechnical University, with individual lectures being given at many other Canadian and US universities and colleges. He has served as a member of various judging panels of competitions and festivals, being one of the members of the first Canadian Film Awards in 1949.

From 1970 to 1975 he was the director of the Stratford (Ontario) International Film Festival, and from 1969 to 1976 he was Chairman of the International Jury of the Canadian Film Awards. He has attended all the world's leading festivals of film, and in particular, for 30 years, the Cannes Festival as CBC correspondent. He has 
written six books, The Films of Frankenheimer: Forty Years in Film; The Cinema of John Frankenheimer; The Cinema of Otto Preminger; The Cinema of David Lean; The Cinema of John Huston, and Torn Sprockets, a history of the Canadian cinema.

Gerald Pratley has served on the Advisory Boards of the film departments of Ryerson Polytechnical University and Humber College, and as a member of the programme committee of TV Ontario. In 1968 he became the founder-director of the Ontario Film Institute of the Province of Ontario, an organization which has distinguished itself in archival holdings and public service and is known since 1990 as the Cinematheque of Ontario. He taught Film History courses at the Department of Film and Photography, Ryerson Polytechnic University, Toronto and the University of Waterloo.

In 1984, Gerald Pratley was made a Member of the Order of Canada and in 2003 Officer of the Order of Canada for his service to Canada through film appreciation. He holds Honorary Degrees in Letters and Fine Arts from York and Waterloo Universities (Ont., Canada) and Bowling Green State University (Ohio, USA).

In 2002, Gerald Pratley received a Special Genie Award from the Academy of Canadian Cinema \& Television in recognition of his lifelong dedication to the promotion and his exceptional support of Canadian cinema.

He died on 14 March 2011 in Ontario, Canada. 